\title{
Research on Training Mode of Financial Professionals in "Professional Docking Industry Chain"
}

\author{
Ye Qian ${ }^{\mathrm{a}}$ and Jingbo Yu \\ School of Finance, Jilin Business and Technology College, Changchun, Jilin Province, China \\ akrain323@163.com, ${ }^{b} 596658069 @ q q . c o m$
}

Keywords: Finance; Discipline; Profession; Industry chain; Talent training

\begin{abstract}
At present, there are still problems in the training mode of talents in the major of finance, such as the non adaptation of professional structure and industrial structure, the homogenization of professional setting, and the lack of specialized local industrialization. In order to solve this problem, we must take the training of technical talents of financial application as the goal, through the docking of "financial profession chain", and make the talent training depth enter the process of enterprise production service and value creation, form the common interest chain and value chain of the cooperation between school and enterprise, and push into the financial industry chain and the integration of personnel training chain. Combining development to better realize connotative development of colleges and universities. This paper, starting with the analysis of the connotation of subject - industry chain. On the basis of analyzing the situation and Enlightenment of the research on the talent demand of enterprises in the financial industry, the paper puts forward the countermeasures and suggestions for the training mode of professional docking industry chain finance professionals.
\end{abstract}

\section{Introduction}

In the process of higher education reform and transformation, some colleges and universities need to find the training objectives and training modes that meet the needs of economic and social development. Therefore, some colleges and Universities under the background of transformation should establish the professional system of close docking industry chain, and set up the specialty in accordance with the demand of high level technical skill talents and the requirements of national professional qualification in accordance with the industrial chain, and make a comprehensive management of the professional cluster of the Association of the same industry chain. In view of this, this article attempts to train the financial practical, skilled, applied specialized talents as the goal, relying on and serving the financial industry chain of Jilin Province, constructing the talent training mode of the cooperative innovation between the financial industry chain and the talent training chain, that is, the "financial professional industry chain" docking mode, successfully completing the university transformation goal.

At present, there are still problems in the training mode of talents in the major of finance, such as the non adaptation of professional structure and industrial structure, the homogenization of professional setting, and the lack of obvious specialized local industrialization. In order to solve this problem, we must take the training of technical talents of financial application as the goal, through the docking of "financial profession chain", and make the talent training depth enter the process of enterprise production service and value creation, form the common interest chain and value chain of the cooperation between school and enterprise, and push into the financial industry chain and the integration of personnel training chain. Combining development to better realize connotative development of colleges and universities.

\section{The Connotation of Discipline, Specialty and Industrial Chain}

Subject - Professional - industrial chain refers to a combination of the interaction or interrelation between a series of related disciplines, specialties and industrial chains, based on a certain industrial chain and serving a certain industrial chain as a purpose. The process of the formation of discipline, 
specialty and industry chain, whether it is subject, professional embedded or industrial chain embedded, is the process of continuous optimization and combination of organizational elements such as discipline, specialty and industry. In essence, it provides a way to integrate resources for talent training. The process of optimizing the combination of disciplines, specialties and industries provides a variety of educational resources for personnel training. Different from the former "discipline and logic" mode of talent training, the model of talent cultivation under the subject Professional - industry chain is presented in the mode of "Employment - employability". In practice, the curriculum system and program of talent training should be built in accordance with the development of the industry and the development of the subject, so that the students not only master the subject and professional knowledge, but also master the knowledge of the industrial development. In the middle stage, the industry related courses are gradually deepened to make it more specialized industry related knowledge; in the high grade stage, students are arranged to carry out internships with industry related organizations or units, or in the form of project operation to drive students to participate in the research and development of the project, in order to cultivate students' comprehensive practice ability.

\section{Investigation and Enlightenment of Talent Demand in Financial Industry}

In order to understand and grasp the basic situation of talent team construction in financial companies and enhance the pertinence and adaptability of personnel training to serve financial industry enterprises, this paper extensively carried out the research work which mainly aimed at the quality and ability demand of the employees. The results of the questionnaire for the survey of capacity requirements are shown in Table 1.

Table 1 Statistical tables of quality requirements for graduates majoring of Finance

\begin{tabular}{|l|c|c|}
\hline option & Number & Proportion \\
\hline Level of theory and policy & 6 & $1.57 \%$ \\
\hline Assimilation and learning ability of professional knowledge & 289 & $75.46 \%$ \\
\hline Innovative research and development ability to tackle key problems & 102 & $26.63 \%$ \\
\hline Judgment & 112 & $29.24 \%$ \\
\hline Planning and planning ability & 178 & $46.48 \%$ \\
\hline Project execution capability & 225 & $58.75 \%$ \\
\hline Market extension ability & 243 & $63.45 \%$ \\
\hline Organization and coordination ability & 179 & $46.74 \%$ \\
\hline Cooperative ability & 317 & $82.77 \%$ \\
\hline Public relations ability & 142 & $37.08 \%$ \\
\hline Expressive ability of language & 156 & $40.73 \%$ \\
\hline Foreign language application and international communication ability & 167 & $43.60 \%$ \\
\hline Conscientiousness & 269 & $70.23 \%$ \\
\hline professional ethics & 267 & $69.71 \%$ \\
\hline The ability to relieve stress and withstand difficulties and setbacks & 287 & $74.93 \%$ \\
\hline
\end{tabular}

In the statistical analysis of the quality requirements of enterprises, we can see that professional knowledge assimilation and absorption of learning ability, market extension ability, cooperation and cooperation ability, responsibility, dissolving pressure, withstand difficulties and setbacks are received by the concern of the enterprises, and the level of theoretical policy, 
innovative R \& D ability and judgment is smaller. This is also related to the career expectations of the new employees, and more basic work for new finance professionals, and less decision making, such as planning and planning. All these results provide a basis for the transformation of teaching mode.

\section{Countermeasures and Suggestions on Financial Professional Training Mode of "Professional Docking Industry Chain"}

Taking the Development of Industry Chain as the Guidance, Creating Characteristic Professional Chain. The local higher vocational colleges should be guided by the development of industrial chain, and its professional setting should be set up according to the adjustment of regional industrial structure and the direction of the development of regional strong industrial chain. The construction of the specialty chain should take the service industry chain as the goal, and take the talent needs of a certain industrial chain as the breakthrough point to construct the professional chain which adapts to the development demand of the industrial chain. To build this specialty chain, we need to build the teacher's talent chain, break through the organizational boundaries of schools and industry enterprises, give full play to the advantages of industry enterprise experts, establish expert database, and promote the exchange and integration of Higher Vocational Colleges and industry enterprises. Combined with the realities of regional industrial transformation and upgrading, higher vocational colleges should use high-quality resources to cultivate distinctive specialties and enhance the employability of higher vocational students.

Building up a Vertically Cohesive Curriculum System with Progressive Ability and Academic Qualifications. Aiming at the students' ability to get professional action, the course teaching plan is drawn up according to the law of learning and growth, and the "ladder progressive" course system of teaching design and teaching content from the basic to the core is set up. In addition, in order to adapt to the "Overpass" education system of higher vocational education, it is necessary to set up a cohesive curriculum system in accordance with the level of educational level, to clarify the level boundary of the similar courses, and to avoid the repetition of the course content of different educational levels.

Construction of Project Guidance, Task Driven Theory and Practice Integrated Curriculum Teaching System for Docking Jobs. We should take the training of professional action ability as the main line, the school enterprise cooperation and development of the core curriculum and practical training materials of engineering work as the main support, the project based curriculum as the main body, the integration of theoretical knowledge and practical skills integration of the integration of curriculum system. Taking the "insurance business management professional group" as an example, the job quality and capability demand is determined through the analysis of typical job tasks of the professional joint insurance contract settlement. And then establish the corresponding professional basis, platform module and professional core module course system, and further investigate the professional qualification standards of insurance companies' underwriting process, professional standards and reinsurance teachers, nuclear indeminers, survey and fixing members and so on, to amend the curriculum standards, select the course content, and then carry out the project. Guide task driven teaching situation design; Further development of curriculum resources, such as teaching presentation module, teaching support module, guidance self-test module and career guidance module, is carried out. The teaching activities such as project teaching, case teaching, simulation teaching and field teaching are carried out with the students as the main body and teachers as the leading part; process and end are adopted. Sex combines curriculum assessment and evaluation, and finally forms a project teaching system of integration of theory and practice.

Construction of Practical Teaching Content System. In view of the demand for ability training, a complete and complete set of practical teaching content system should be constructed, including curriculum design, curriculum paper, practice, simulation training and graduation design. By setting up the relevant practical content to realize the related ability training, the practice of English communication ability and computer application ability is mainly completed in the course of course 
teaching. Skills training in the professional field is accomplished in the following steps. Talent training programs should highlight skills training in the professional field so as to enhance students' perceptual knowledge and hands-on ability in professional knowledge and skills. In particular, the practical training section covers the practical operations involved in the various directions of the financial profession, including the simulation of futures trading, the business simulation of commercial banks, the simulation of securities investment and transaction, and the simulation of insurance marketing business. To improve the past education and training plan, the professional skills system is unreasonable and the direction of nurturing is not prominent. Let's see the progress of practice teaching (Table 2).

Table 2 Practice teaching process

\begin{tabular}{|c|c|c|c|c|c|}
\hline Name of practice project & Semeste & weeks & credit & Content & Remarks \\
\hline Health Education & 1 & 0.5 & 0.5 & $\begin{array}{l}\text { Helping students to build up a healthy } \\
\text { personality }\end{array}$ & In school \\
\hline \begin{tabular}{|l} 
labor for the collective \\
welfare
\end{tabular} & 3 & 1 & 0.5 & Take part in the service labor in the school & In school \\
\hline Military theory and training & 1 & 3 & 3 & $\begin{array}{l}\text { Carry out national defense education and } \\
\text { military skills training }\end{array}$ & In school \\
\hline Understanding practice & 2 & 1 & 1 & Introduction to finance major & Outside school \\
\hline \multirow{4}{*}{$\begin{array}{l}\text { Simulation training of } \\
\text { Financial Specialty }\end{array}$} & 3 & 1 & 1 & Bank savings business simulation training & In school \\
\hline & 4 & 1 & 1 & Bank credit business simulation training & In school \\
\hline & 5 & 2 & 2 & $\begin{array}{l}\text { Simulation training of insurance and securities } \\
\text { business }\end{array}$ & In school \\
\hline & 6 & 1 & 1 & $\begin{array}{l}\text { Simulation training of financial integrated } \\
\text { business }\end{array}$ & In school \\
\hline Financial curriculum design & 6 & 1 & 1 & $\begin{array}{l}\text { Analysis and design of financial investment } \\
\text { tools }\end{array}$ & In school \\
\hline Professional practice & 7 & 10 & 10 & Professional comprehensive practice & Outside school \\
\hline Graduation education & 8 & 1 & 1 & $\begin{array}{l}\text { Independent life and professional spiritual } \\
\text { education }\end{array}$ & In school \\
\hline Graduation practice & 8 & (4) & 4 & Collecting papers on graduation thesis & Outside school \\
\hline Dissertation & 8 & 12 & 12 & $\begin{array}{l}\text { Comprehensive application training of } \\
\text { professional knowledge }\end{array}$ & Outside school \\
\hline Professional social practice & 5 & 2 & 1 & Investigation of financial hot issues & Outside school \\
\hline \multirow{3}{*}{ Term paper } & 4 & 2 & 0.5 & \multirow{3}{*}{$\begin{array}{l}\text { A literature review paper combined with } \\
\text { semester courses }\end{array}$} & \multirow{3}{*}{ In school } \\
\hline & 5 & 2 & 0.5 & & \\
\hline & 6 & 2 & 0.5 & & \\
\hline $\begin{array}{l}\text { Social practice in the course } \\
\text { of Ideological and Political } \\
\text { Theory }\end{array}$ & 1 & 2 & 1 & $\begin{array}{l}\text { Understanding society, understanding national } \\
\text { conditions and cultivating character }\end{array}$ & Outside school \\
\hline \begin{tabular}{|l}
$\begin{array}{l}\text { Ideological and moral } \\
\text { cultivation and legal basis }\end{array}$ \\
\end{tabular} & 1 & 3 school hours & \multirow{5}{*}{2.5} & \multirow{5}{*}{$\begin{array}{l}\text { Take part in the social survey and complete the } \\
\text { course paper }\end{array}$} & After class \\
\hline $\begin{array}{l}\text { An introduction to Mao } \\
\text { edong thought and the } \\
\text { heoretical system of socialism } \\
\text { ith Chinese characteristics }\end{array}$ & 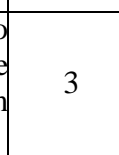 & 18 schoolhours & & & After class \\
\hline $\begin{array}{l}\text { Outline of modern Chinese } \\
\text { istory }\end{array}$ & 2 & 6 schoolhours & & & After class \\
\hline $\begin{array}{l}\text { The basic principle of } \\
\text { Iarx's doctrine }\end{array}$ & 5 & 9 school hous & & & After class \\
\hline \begin{tabular}{|l|l|}
$\begin{array}{l}\text { College Students' mental } \\
\text { ealth education }\end{array}$ &
\end{tabular} & 3 & 8 schoolhours & & & After class \\
\hline Form and policy & $1-6$ & 68 schoolhours & 1 & $\begin{array}{l}\text { Special reports, organizing listening, watching, } \\
\text { discussing and discussing current affairs news }\end{array}$ & After class \\
\hline Development of quality & $1-6$ & & (13) & $\begin{array}{l}\text { Ideological and political and moral evaluation, } \\
\text { academic science and technology and } \\
\text { innovation and entrepreneurship, skill training } \\
\text { and qualification certificate, stylistic art and } \\
\text { physical and mental health, social practice and } \\
\text { volunteer service, community activities and } \\
\text { social work }\end{array}$ & After class \\
\hline
\end{tabular}




\section{Projects}

(1)Research project of higher education reform in Jilin province: Research on the technical personnel training mode of "financial professional — industry chain" in Jilin province

(2)Research on EPSS design of internship in application oriented university based on mobile Internet (JGJX2016B24)

\section{References}

[1] State Council. Decision on accelerating the development of modern vocational education.[2014]No. 19,2014-05-02.

[2] zhibing huang. Research on talent training mode of "professional industry chain" in Higher Vocational Education. Journal of Ningbo University.2014(1).

[3] Huiliu,Zhigang Qian. Subject specialty industry chain: Exploration of transformation development path of Applied Undergraduate Colleges. higher education of sciences.2015(6).

[4] Liu Hui. Liu Zhigang. Discipline-Specialty - Industrial Chain: Exploration of Transforming Development for Application - Oriented Universities. Higher Education of Science,2015(6):19-20.

[5] Feng Zichuan.Study on Reform and Practice of the Training Mode of Garment Professionals in Professional Docking Industry Chain. Vocational and Technical Education in China,2015(8).

[6] Xiao Juping. Study on the Professional System Construction of Insurance Vocational Education Docking with Insurance Industry Chain. Journal of Insurance Professional College,2016(2). 